\title{
Revisiting the Classics and the New Media Environments: Shakespeare Re-Told by Jeanette Winterson, Margaret Atwood and Edward St. Aubyn
}

\begin{abstract}
The versatility of the appropriation of Shakespeare in recent years has been witnessed in a variety of registers and media, which range from special effects on the stage, music, cartoons, comics, advertisements, all the way to video games. This contribution looks at some of the novels in the Shakespeare Re-told Hogarth series as effigies of the contemporary process of adapting the Elizabethan plays to the environments in which the potential readers/viewers work, become informed, seek entertainment and adjust themselves culturally, being, ultimately, cognitive schemes which are validated by today's reception processes. The first novel in the series was Jeanette Winterson's Gap of Time (2016), in which the Shakespearean reference to the years that separate the two moments of The Winter's Tale's plot becomes the title of a video game relying mainly on fantasy. Margaret Atwood's Hag-Seed (2016) rewrites The Tempest as a parable of the theatrical performance and its avatars, as undisputable authority, on the one hand, and source of subversiveness, on the other. Dunbar (2018) is Edward St. Aubyn's response to the family saga of King Lear, where kingship, territorial division and military conflict are replaced by modern media wars, and the issues of public exposure in the original text are reinterpreted interpreted by resorting to the impact of the audio-visual on every-day life.
\end{abstract}

Keywords: adaptation, Hogarth Shakespeare, media, performance, video game.

\section{Introduction}

Desmet and Sawyer's book about Shakespeare and appropriation signalled, already in the $1990 \mathrm{~s}$, a radical shift in the study of literature, from text to context, resulting in the complete renunciation of reading the Bard's plays as independent aesthetic objects. The process of appropriating Shakespeare, carried either on a big scale, making him an institution of the establishment, or on

* Department of Modern Languages, the West University of Timişoara, Romania. 
a small scale, with individualized or local revisitations, started long before the concept of appropriation gained a theoretical standing. Big-scale Shakespeares are David Garrick's performances and the Stratford Jubilee, which presented the playwright as the most outstanding genius of British culture and the embodiment of the superior British spirit. The Romantic taste capitalized not only on the Shakespearean poetic language, but also on the visual representation of plots and characters, with great emphasis - seen in Henry Fuseli's art, for example - on the tension between light and darkness. The Pre-Raphaelite Brotherhood, in painting scenes from Shakespeare, acknowledged the importance of décor and setting, displaying a recognizable Italian Renaissance architecture, well-liked by the British who took the Grand Tour to Mediterranean Europe to complete their education. Charles and Mary Lamb's Tales from Shakespeare responded to the sensibilities of the Victorian middle class, with neither too much passion, nor too much violence, the story being often reduced to an unambiguous linearity and a reassuring effect on readers of all ages. Another written medium which transforms, sometimes beyond recognition, the Bard's text is the script: the farce and the burlesque in the silent films, is followed by the lavish, colourful mega cinema productions, the canonical TV series, suitable as teaching aids, or the popular spin-offs, in which the early modern plot is transported into a contemporary context. While some of these are rightly labelled as highbrow or lowbrow, a project at the crossroads between "big-time" and "small-time" Shakespeare, combining the missions of conservative ideology and the personal acts of discovery and survival via Shakespeare is the Hogarth Shakespeare project.

Postmodernism has taught us that there is no reading without rewriting and the problem of writing something new is a formidable challenge for all writers. One may argue that things were quite similar for Shakespeare, too, since most of his plots were borrowed from the Italian Renaissance, from French romances or from his contemporary Elizabethan playwrights, plus a touch of history from the English chronicles, for good measure. But today's inclusive, global, intertextual awareness has made the reading of one text against another compulsory, and thus the pressure for "originality" has become more dramatic, and the experience of reading and re-writing literature has become a pluridimensional act. The rewritings on Shakespeare's plays in the Hogarth project are, therefore, not "reimaginings," but "reactions" to Shakespeare, with a focus not on the story as such, but on the "twists" in the story (Gopnik) that articulated the major themes Shakespeare studies discuss today: gender roles and gender relations, racial intolerance and anti-Semitism, isolation and exploitation, authority and legitimacy. Reviews of these rewritings reiterate an aspect which is generally explained by studies in appropriation: "If Shakespeare is our contemporary, it is not because he shares our attitudes but because he shares our agonies" (Gopnik). The novels in the Hogarth series, like many spin-offs, 
can make readers tick because they are effigies of the contemporary process of adapting the Elizabethan plays to the environments in which the potential readers/viewers work, get informed, seek entertainment and adjust themselves culturally, being, ultimately, cognitive schemes which are validated by today's reception processes.

Initiated by the prestigious London publishers Hogarth (established, in the interwar period, by none other than Virginia Woolf), Hogarth Shakespeare was meant to capitalize on the celebratory mood of the English-speaking world, which, in 2016, counted four centuries since the Bard had become a major cultural icon. The publishers commissioned several important British, American and Canadian writers to propose novels that would move the plot of some famous tragedies and comedies from the Elizabethan stage into the contemporary world. Jeanette Winterson opened the series, with the rewriting of The Winter's Tale as The Gap of Time (2015). She was followed by Howard Jacobson's Shylock is My Name (2016), an obvious modernization of The Merchant of Venice, by Vinegar Girl (2016), an original approach to The Taming of the Shrew offered by Anne Tyler, Hag-Seed (2016), in which Margaret Atwood rewrote The Tempest, Tracy Chevalier turning Othello into New Boy (2017), Edward St Aubyn responding to King Lear in Dunbar (2018), or Jo Nesbø, as an author of crime novels, rewriting Macbeth (2018). The three novels discussed in this paper are a successful example of the phenomenon described above because they make even the most artificial or mechanical aspects of the plays seem plausible by setting them in a familiar medium.

\section{Angels and Avatars in an Interactive Medium}

Jeanette Winterson, herself a "foundling," confesses having felt drawn from an early age to Perdita's plight and the wondrous family reunification at the end of The Winter's Tale. But this empathy did not help in trying to come up with a plausible, modern interpretation of the fantasy, which cast statues brought to life and other logically impossible twists and turns of the plot. King Leontes' inexplicable transformation from devoted husband into jealous despot and then, much later, back into a humane father, Perdita's extraordinary survival in the wilderness, the pastoral romance with Florizel, the coincidences of parentage and friendship, are all elements of a fairy tale plot, which have disappeared from contemporary narratives. So, Winterson retrieves the fantasy by inserting the weight of video games, a modern, technologized version of escapism into a world of magic - and a way to make lots of money and rule, without a crown or a sceptre, over a digital empire. Shakespeare's exotic Sicilia and Bohemia are present-day London and a provincial American town, New Bohemia; the good shepherd who raised Perdita is now an African-American; queen Hermione is 
a French dancer and singer, etc. The absence of an atmosphere of fantasy is compensated by Winterson's preference for philosophy, the book being permeated with thoughts about love, innocence, and dreams. And, of course, about time, as the very title of the novel announces.

The gap of time is made up, in Shakespeare's romance, of the years that pass since King Leontes banished his child until he is reunited with his family, a respite to meditate about all that happened in the meantime. This gap is, thus, a chronological breach, which facilitates a mental time travel. The phrase appears in the name of the video game Xeno/Polixenes invents, based on the story of the Shakespearean heroes, and secures the link between three temporal levels (Elizabethan England, evoked by the original romance, contemporary London/New Bohemia, nineteenth-century Paris, in which the game takes its players) and three environments (the Shakespearean text and stage, the postmodern rewriting, the virtual world of the computer). This is further complicated by the fact that the author's avatar is present in the mixed-media story: on the one hand, Winterson herself announces her presence as spectator at the end of the story: "I was sitting at the back, waiting to see what would happen, and now I'm out on the street in the summer night, the rain tracing my face" (284). On the other hand, the creator of the video game is present in his virtual world; Xeno transmutes his real-life memories of his youth in Paris, when he courted MiMi for his friend Leo, into an epic battle taking place in the Paris of the nineteenth-century Boème, the atmosphere being spiced up with a touch of Steampunk.

In Shakespeare's The Winter's Tale, personified Time recites the prologue of Act 4, announcing technically that the story continues 16 years later, but, at the same time, reminding spectators and, in general, users of fiction, that art makes chronology flexible, freezing the moment or stretching it, moving easily back and forth on the temporal axis:

I, that please some, try all, both joy and terror

Of good and bad, that makes and unfolds error,

Now take upon me, in the name of Time,

To use my wings. Impute it not a crime

To me or my swift passage, that I slide

O'er sixteen years and leave the growth untried

Of that wide gap, since it is in my power

To o'erthrow law and in one self-born hour

To plant and o'erwhelm custom. $(4: 1: 1-9)^{1}$

\footnotetext{
1 All quotations of Shakespeare are taken from David Bevington's edition.
} 
This is what modernism discovers and illustrates with the stream of consciousness. Proust's time lost and regained is nothing but a temporal ambiguity and fluidity. Aware of this, Winterson goes even further, giving this subjective approach to time an oneiric touch in the evocation of French poet Gérard de Nerval. A late Romantic, a symbolist and a precursor of Surrealism, Nerval plays in his works with the thin line between imagination and reality, between the power of the artistic genius and mental instability. Suffering from hallucinations and severe depressions for long periods of time, being even admitted to asylums on several occasions, Nerval imbues his literary vision with this autobiographical note, leaving the impression that this tormented personal experience is verging on mysticism. Moreover, he identifies himself intensely - even desperately - with his fictional characters, the female ones being sublimated versions of a lost youthful love. One of the most powerful poems he wrote, "El Desdichado" (in Spanish, in the original, meaning "the unhappy, desperate one") in 1854, starts from the image provided by the Romantic writer Walter Scott in his black knight. While the medieval character proclaimed his despair at having been dispossessed of honour and noble title, Nerval's lyrical ego deplores the void he feels after the disappearance of his love, which renders any chance of consolation impossible. The gallery of figures he evokes is completed by Cupid, Phoebus, and Orpheus. The first two suggest the poet's oscillation between two major states of mind, consuming passion and stabilizing reason. This dilemma remains, though, unsolved, as Nerval cannot choose whether despair is to be treated emotionally or rationally, but an implied solution that might reconcile both is art, embodied by the lute player. Nevertheless, this aesthetic consolation is short-lived, as Orpheus' plight is tragic: going to Hades to take back his beloved, the poet loses her forever when he succumbs to his all too human weakness, the need to look back and make sure she is there, returning to the world of light. The evocation and memory of love is so vivid that it seems almost real, while, in fact, it is a mere illusion. The path chosen by Nerval to console himself with this realization is to push the imagery in his poetry and prose even further into the realm of the dream.

Winterson's idea to bring to the contemporary reader's attention Gérard de Nerval's personality and artistic creed appears, in these circumstances, less arbitrary. In the Parisian intermezzos, she imagines, as a counterpart of the Time prologue in Shakespeare's romance, Nerval is a domineering figure. MiMi, who is a famous and cultivated singer, uses lyrics inspired by Nerval's poetry, and Xeno invents a video game inspired by Nerval's fallen angel. This angel lives a dilemma as tragic as those of the French poet himself: falling one day from Heaven in the narrow yard of a house in the poorer neighbourhoods of Paris, his choice is extreme. His great wings trapped between the four grey walls of the building, if he wanted to escape, he would destroy the entire street; if he stayed, he would wither and die. The former option, while following a basic survival 
instinct, is not possible, because it would kill the beautiful girl the angel befriended, the only human who keeps him company, day and night, as he is shrinking, the ultimate proof of kindness and love:

When the angel became trapped his head was level with the upper floors of the houses and a little child used to come and talk to him. She sat on the windowsill, her knees drawn up against the cold, and she told the angel stories her mother had told her, so many stories of lost and found, and the angel loved her.

At night, sometimes, she'd bring a candle to the window and sit with the angel because she knew he was lonely.

Weeks passed and the angel began to die. As he died, he shrank, and the child went from window to window, zigzagging down the house, her small body by his great fallen head. (Winterson 204)

This beautiful story, in Winterson's vision, is a replica of a dream Nerval recounted having had a few days before his death. Feeling painfully lonely and separated by death from the young actress he once loved, the poet hanged himself one night from the bars of a window in one of those narrow and impoverished streets of Paris where his own dream had occurred.

Winterson borrows from Nerval the intensity of love and loss and bestows it upon her Shakespeare-replica tale and characters, concentrated in the game Xeno invents and which becomes a cameo of the main message of the story, gravitating around separation and reconciliation, guilt and longing. When Xeno creates the game, he exclaims: "Nerval didn't go beyond the trapped angel; that was his dream. My dream was the child and the promise" (Winterson 205). The oneiric universe is translated into the virtual reality of the computer, where a nineteenth-century Paris at night is covered in the feathers of fallen angels who want to conquer the city and the players' avatars are supposed to fight them with their own weapons - the feathers which can swell or combust. The game has nine levels and, the more advanced a player is, the more unusual his powers become. From level 4 on, time can be frozen, moved around, rewound, made to "unhappen" (Winterson 206). Xeno's wish corresponds to something similar nurtured by Leo, who remembers a movie he used to enjoy with his son, Milo, in which Superman flew so fast around the Earth's axis that he forced time to go back and saved Lois Lane from drowning in the waters of a broken dam.

In Xeno's game, the love triangle from Shakespeare's romance becomes a projection of avatars whose agency has various degrees of limitation. The most limited and passive is MiMi, a mere object in this virtual medium. While Xeno suspects that she is still alive and lives in complete seclusion in Paris, being rarely seen outside the house, he can never be too certain and so he designs her, in the "Gap of Time," as a ghost: 
She was as she was. Lying like a tomb knight in a chapel. White and made of stone. The room with the double windows that overlooked Notre Dame was a tiny white world where nothing moved or changed. She was Sleeping Beauty who wouldn't wake up. There was no kiss.

She was always here but she could be elsewhere. Walking like a statue through a statue garden. Alive and not alive. Sleeping and not sleeping. She is by the river sometimes. They say it's her. (Winterson 219)

This image rewrites the original version, in which Hermione is kept in hiding for 16 years by loyal Paulina. Her habitat, while being a sanctuary against King Leontes' initial rage, gradually transforms into a prison-uncomfortable and impersonal, this is a place she cannot leave, where she cannot be seen or heard for a long time. When Paulina invites the king to visit it, she presents it as a chapel, therefore a chamber in which the queen must have found spiritual comfort, the strength conveyed by Christian teachings to forgive her husband and to bear the loss of her two children. Hermione is returned to her family under the pretence of a statue, proof that art not only imitates reality, but offers an improved version of it. Xeno's game copies the literal reference to the statue and processes the scarce original information about the queen's place, enriching it with details: a frozen, claustral universe filled with sadness and loneliness, but sheltered. Outside MiMi's window, both the men she loved long to be let in, but in vain-Xeno, fluttering like a moth, Leo, "hurl[ing] himself at the glass that would not break" (Winterson 209). The male players' agency is less limited, even if their ability to move around only gives them the illusion they can act. Their plea to be admitted back into MiMi's life is in accordance with their temperament: Xeno, shy and discreet, Leo, demanding and aggressive.

Winterson's imagining the video game as one in which time could be manipulated to the players' best interest is a side comment on how tragic tension is actually created in Shakespeare's text, with the careful dosage of information the playwright offers at various stages in the plot development. While there are several (sad) certainties about the events of the past-Mamillius' death, Perdita's abandoning and rescuing the shepherd - there are also developments deliberately left unclarified: Hermione's fate and King Leontes' change of heart. In the novel, Winterson chooses to freeze time differently, reassuring us about Perdita's fortunate adoption and giving us hope about MiMi, but leaving young Milo's disappearance unexplained. It takes 16 years before the readers learn that, running away from the check-in desk at the airport, the child was run over by a luggage van and died.

In fact, it is thanks to Jeanette Winterson that we become sensitive to the very use of time, alternatively contracted and dilated, in creating the suspense of the original Shakespearean plot. Additionally, this realization helps contemporary readers and viewers of Shakespeare grow more aware about the importance of 
the medium in the appropriation of this type of literature. While initially meant only for the live stage, the plays were confiscated by the nineteenth-century literary criticism, the development of the cinema and television seeing the plays swallowed by the audio-visual media. Given the growing number of video games which announce an affinity of sorts with the Bard, we can assume that the twenty-first century is the age of virtual Shakespeare. Xeno's invented game, while quoting from Shakespeare in the title, is concentrated on a battle, as most video games are fuelled by the epic substance of some battle or other-here, the clash between the fallen angels and the Parisians. As the film industry has constantly sought a source of inspiration in Shakespeare in order to gain credibility and cultural authority, the video-game industry seems to follow a similar path, in search for aesthetic validation. Thus, the battles fought on the screen, between the players' avatars and graphically designed characters, announce a larger, more abstract battle, the one fought by the medium for its own upgrade. A quality of the video-game format, which Winterson acknowledges, is its interactive nature, more interactive than even the original Elizabethan stage was, with all the cheering and booing and throwing coming from the stalls. Never before the virtual era has the reader or viewer been taken out of a mainly passive, contemplative attitude and hurled straight into the action.

\section{The Play within the Novel}

Margaret Atwood's response to The Tempest seems to be "so much like something Atwood would have written anyway" (Groskop). It is true that most of the books or films which are adaptations of Shakespeare's last play filter the reception of Prospero's and Caliban's stories in the postcolonial context. In the 1980s, scholars were already summing up interpretations of The Tempest in these terms: "It has long been recognized that The Tempest bears traces of the contemporary British investment in colonial expansion" (Dollimore and Sinfield 48). This was enough to legitimize interpretations of The Tempest as a piece of imperialistic ideology, with a British colonizer imagining himself a member of the superior race, and primitive subjects following the pattern of the good savage and the bad savage. Prospero, rather than a magus, is a usurper, Ariel is not a spirit, but an expert in adaptability, while Caliban is not a monster, but a victimized native. A more classical and atemporal reading of the play interprets it as the Bard's testament: at the end, Prospero buries his books, saying good-bye to magic, to the island and, of course, to the Jacobean stage.

In Hag-Seed, Margaret Atwood leaves aside the most predictable interpretations, enabling readers to view the story as a parable of theatrical performance, concomitantly a mainstream manifestation and a source of 
subversion. Exploiting the potential of the "farewell to the stage" interpretive version, Atwood comes up with an equally metatextual scenario. Shakespeare's Prospero went through a retirement in two phases, the first one in which he was exiled from his European dukedom on a deserted island and the second one in which he renounced his passion for magic in order to take up the political career he had avoided in the first place. Atwood offers her new Prospero, now called Felix Philips, artistic director of a Canadian drama festival, a retreat which is not far from what she gave her first heroine, in the 1972 novel, Surfacing. Felix goes down literally after his assistant plots against him and takes his job while he is busy staging the performance of a lifetime, the most daring version of The Tempest. His retreat, rather than an exotic island in the Caribbean, is a wooden cabin which looks as if it had not been inhabited since the pioneering days of the Western frontier. Just like in these old days, the place is far from civilization, accessible from the main road in the summer but totally isolated in winter. This is the perfect escape for Felix, who must heal two severe wounds: the loss of his social position and, more tragically, the death of his three-year-old daughter, killed by meningitis and called Miranda. The rustic décor is reminiscent both of Prospero's cave, a sheer contrast with the court life the duke left behind and an improper place to raise a daughter like a lady, and of the wilderness in Surfacing. Atwood's early novel featured a heroine who travelled to the Canadian interior in order to be symbolically reunited with her father, a scientist who had lost his life exploring the natural life. While carrying out this investigation, the heroine is more and more seduced by the wilderness, with its bare truths and lack of sophistication. Protesting against consumerism, mass tourism, male domination, pollution and the destruction of wildlife, the heroine gradually rejects all forms of civilization, from processed food and clothes to articulated speech, choosing to live and give birth to a child in the depths of a forest. The novel is open-ended, the final scene showing the same heroine standing in between the two worlds, the forest on the one hand and the boat carrying her fiancé and friends on the other.

For Margaret Atwood, victimization is one of the major tropes of Canadian literature, regarded in a progressive manner, as an evolution in four steps: from anger, through resignation, to experimentation and creativity. In the fourth position of the victim, the subject becomes aware that this is not a passive status, but an attitude with a highly dynamic potential (Atwood 38). Faced with the challenge of survival — which can be physical, moral or aesthetic - the victim can turn adversity into her own advantage. This trajectory, sketched theoretically in the 1970s, is revisited in Hag-Seed, where Felix disappears from public life for some years before resurfacing in the most unexpected manner. In the wood cabin, he fights both the aggression of wild nature and the pressure of his melancholy and depression, repeating, symbolically, the path taken by Atwood's pioneer, in an early poem. "Progressive Insanities of a Pioneer," initially 
published in the collection The Animals in That Country, was conceived as a reaction against the standard image of the pioneer, inherited from the nineteenth century, as a heroic, exemplary figure, and as an illustration of Atwood's enthusiastic embrace of ecocriticism. The pioneer starts with the selfconfidence and self-sufficiency of the colonizer, but ends up being defeated by the vast open space which he cannot control and understand. Felix's retreat implies complete isolation and the life of a hermit. For years, he grows a beard and eats only in order to stay alive, being haunted by the image of his daughter. Rather than spiritual revelation, he finally emerges with the need to get back in contact with the real world and his old profession, manifested in his acceptance of a job as drama teacher in a prison. Calling himself Mr. Duke in honour of the rightful Duke of Milan in Shakespeare's play, Felix prepares a gathering storm with the help of theatrical magic. When his lessons become a success, and he receives the visit of high officials, none other than the two men who sabotaged him at the Makeshiweg Festival in the past, this becomes Felix's chance for payback.

If the original Prospero prospered on the island because he had his books and his daughter with him, Felix's happiness (as his Latin name implies) is harder to achieve, though not impossible, and his satisfaction comes from the most unexpected details. His new and menial job soon turns out to please him more than he would have expected: in the absence of his past fame, professional esteem and large amounts of money invested in his projects, Mr. Duke is happy to realize, while training inmates, how little it actually takes for someone to be happy. He is deeply moved by the criminals' child-like joy in seeing themselves acting, on the closed-circuit television available at the Fletcher County Correctional Institute. Now comes the real coup de théatre, the device of the play within the play or within the novel, which Shakespeare, while not using in The Tempest, resorted to quite frequently. The larger frame is that of Felix's life and work, implicitly reminiscent of Prospero's failed politics and successful magic. At the core of the framed story, there are the two main adaptations of The Tempest, the lavish, very expensive performance prepared by Felix just before he is fired, and the lesson taught to the prisoners, many years later. If many connections can be identified at the level of the plot, structurally the novel is also a replica of the Shakespearean play. Hag-Seed's chapters are arranged in five parts, similar with the five-act organization, the titles alluding either to Atwood's earlier theories (Dark Backward), or to the Shakespeare Concordance (A Brave Kingdom, These Our Actors, Rough Magic, This Thing of Darkness), "hag-seed" being also one phrase in the long list of invectives Shakespeare uses in this play and others. The use of curse words capitalizes on the educational and therapeutic potential of teaching Shakespeare to the inmates: no matter how rough or dangerous these men are, they know they cannot swear unless they use the Bard's words. Any play will do at first, but as the students become more 
advanced, their selection narrows down to the play they are learning at that moment. The most imaginative quoters are given cigarettes, smuggled in the prison by their teacher. During a rehearsal for Macbeth, two inmates may call each other names saying: "The devil damn thee black, thou cream-faced loon" (Atwood 6). And The Tempest comes with a long list of swearings:

Born to be hanged. A pox o'your throat. Bawling, blasphemous, incharitable dog. Whoreson. Insolent noisemaker. Wide-chapp'd rascal. Malignant thing. Blue-eyed hag. Freckled whelp hag-born. Thou earth. Thou tortoise. Thou poisonous slave, got by the devil himself. As wicked dew as e'er my mother brushed. With raven's feather from unwholesome fen, Drop on you both. A south-west blow on ye, And blister you all o'er. Toads, beetles, bats light on you. Filth as thou art. Abhorr'ed slave. The red plague rid you. Hag-seed. All the infections that the sun sucks up, From bogs, fens, flats, fall on - add name here-and make him, By inch-meal a disease. Most scurvy monster. Most perfidious and drunken monster. Moon-calf. Pied ninny. Scurvy patch. A murrain on you. The devil take your fingers. The dropsy drown this fool. Demi-devil. Thing of darkness. (Atwood 91)

In this way, it can be easily argued that the play within the novel is an occasion, for writer and readers, to rediscover the hidden potentials of the Bard's last play, down to the most minute lexical details. Atwood's novel can also be read as a selection of the most eccentric stage adaptations of Shakespeare ever to have been recorded around the world. The friendly critics labelled Felix's performances at the Makeshiweg Festival daring, while the more aggressive ones went as far as to call the artistic director demented. His Titus Andronicus featured a naked, genuinely bleeding Lavinia, his Pericles took place on a spaceship invaded by aliens, in The Winter's Tale Hermione was not a moving statue but a vampire, while Julius Caesar was not set in ancient Rome but in Scotland, with the senators dressed in tartan. But these were the vanished days of theatre glory. Now, as Mr. Duke, the director, has no money to invest in artistic experiments and needs to follow a lot of safety rules: characters cannot fight on the stage because they would incite violence; they cannot use bad language because there is a strict behavioural code in prison; suicide cannot be mentioned because it happens all too frequently in the cells; while costumes, music or special effects would cost too much: "nothing sharp, nothing explosive, nothing you could smoke or inject" (Atwood 57). The effect of the performance on the audience cannot be checked either, because large crowds are banned for fear of a riot; so, neither cheering nor boos from the public can inform Felix about the success of his ideas. In the past, even the most severe criticism was gratifying, as he believed that "Where there are boos, there's life!" (Atwood 13) Now, his greatest motivation is to watch the men's pride in their fleeting celebrity, an experience which is more rewarding than all the public attention of bygone days. 
Of all Felix's productions, The Tempest has always been his ultimate challenge. At the Makeshiweg Festival, the staging included Ariel as a transvestite on stilts, Caliban as a homeless African American, Miranda as a child gymnast, and Prospero dressed in animal skin made of plush toys which had been unstuffed and sewn together. At the Fletcher Correctional Facility, the cast is more predictable: a con artist with large eyes as Ferdinand; a slender, cool juvenile hacker as Ariel; Snake Eye, the real-estate fraudster, with his slanted left eye and lopsided mouth, as Antonio. For Miranda, Felix searches for the same gymnast, now a professional actress, who accepts the invitation with curiosity and excitement. Felix works with an abridged Shakespearean script, sprinkled with prison slang and collocations, full of local colour, which resonates, in its crudeness, with the interpreters' illiterate naivety. The prologue, announcing the storm at sea, includes the following lines:

ANNOUNCER: What you're gonna see, is a storm at sea:

Winds are howlin', sailors yowlin',

Passengers cursin' 'em, 'cause it gettin' worse:

Gonna hear screams, just like a ba-a-d dream,

But not all here is what it seem,

Just sayin'.

Grins.

Now we gonna start the playin'.

(Atwood 3)

If we are to compare this with the original "Blow, till thou burst thy wind" (1:1:7), or "What cares these roarers for the name of king?" (1:1:16-17), it is hard to see a trace of the theatrical illusion that was one of the major assets of the Bard's story about magic as art. But the alteration of the poetic script, to the benefit of conmen and criminals, points at one direction of Shakespearean appropriation which has gained momentum in recent years. Indeed, as Marjorie Garber notices in her Shakespeare and Modern Culture, the playwright's legacy and utility prove to be, today, perhaps more rewarding in unconventional environments (xviii). Rather than the regular classroom, lecture room, or theatrical stage, Shakespeare is employed for lessons in leadership, problem solving, and business success for corporate culture, for boosting the morale and improving self-image in therapy groups, or even for re-education.

\section{Privacy, Public Exposure and the Audio-Visual}

If The Taming of the Shrew is hard to digest by contemporary sensibilities trained in the climate of gender equality and equal opportunity, King Lear seems almost unbearably patriarchal. One of the most seminal studies about parental 
and generational conflicts in this play and about masculine authority and prejudice presents it as such as early as 1986 (Coppélia Kahn's The Absent Mother in King Lear). The old king's response to the events of the tragedy in an intense combination of love and hatred, care and violence is interpreted by Stephen Greenblatt (qtd. in Kahn 253) as an illustration of a "deep gerontological bias" that, in Elizabethan literature as well as legal texts, was well-researched. Inter-generational transactions were common, and very strict and explicit contracts were signed between parents and children, in case the former decided to leave their earthly possessions to the latter. Some of these contracts, it seems, were clarifying to the point of stipulating the quantity and ration of food children should provide daily for the parents now in their care, this exactness seemingly compensating for or regulating the natural generosity or lack thereof. Therefore, the Shakespearean daughters' insensitivity and the father's frustration at witnessing it were not, in the seventeenth century, unheard of. What makes the story really hard to swallow is, besides the daughters' exaggerated cruelty (whose major victim is, in fact, not Lear, but his former dependants), Lear's equally exaggerated male self-centredness. King Lear seems to be the most masculine of Shakespeare's tragedies, because of the daughters' stereotypical maleness and despite their father's effemination. Goneril, in her fury and aggressiveness, kills a servant with a sword, an utterly male weapon, in contrast with Lear, who sheds "women's weapons, water-drops" (2:4:279) in his despair and frustration. The play's exclusive gravitation around the father's broken expectations and humiliation is justified, Kahn believes, by a social mutation that takes place in the early modern period, when, unlike earlier ages, the father's dominance in the family, especially in the upper classes, due to the rules of patrilineality and primogeniture, is at its most evident. Lording over a large number of people, the pater familias was a public figure even in the nonpublic, domestic environment of his home.

Against this background, we must observe Lear's gestures from the very beginning of the play, when he summons the entire court to witness what seems an exchange of affections between himself and his three daughters, to the very end, his rage against his elder daughters and his refusal to accept Cordelia's death being all played out in the presence of his dependants. Thus, even the most intimate workings of the nuclear family are exhibited in front of a group representative for an entire community, as privacy was an asset not yet acknowledged by Shakespeare's contemporaries. It is not far-fetched, then, that Edward St Aubyn transfers this excess of visibility and lack of privacy into his response to the play, the kingdom becoming a media corporation, where all the secrets of the protagonists are revealed for public consumption. Shakespeare's metaphor that all the world's a stage is given, in this novel, another dimension, which highlights the vulnerability of the modern individual through repeated exposure. A media mogul, Dunbar-Lear has ruled with an iron fist, making and 
breaking destinies by naming and shaming important men and women in his newspapers and TV channels. In today's world, this is the ultimate form of power, stronger than that of state rulers, politicians, leading industrialists or bankers. "Nobody understood power better than your father" (St Aubyn 5), Charlie Wilson, aka Kent, tells Florence, aka Cordelia, a deliberately ambiguous characterization which can be a compliment as much as a reproach. This power is described as being operational on every continent, and the ability to get in touch with any leader, to "influence elections and destroy enemies" resulting from the ability "to spin or bury a story" (St Aubyn 55). That power in general may be ambiguous is true, but media power, it is implied, is the most duplicitous, dangerous and domineering of all, taking, at Dunbar's hands, the shape of "cheap debt and plummeting standards" (St Aubyn 96).

The audio-visual media of the twentieth and the twenty-first centuries corresponds to the wooden $\mathrm{O}$ of early modern entertainment and the Renaissance processing of the concept of blind destiny borrowed from the Greek tragedy. For Shakespeare's audiences, the cynical randomness of human fate, puppeteered by the gods' whims, was softened by the Christian promise of redemption, cold comfort, as this was already in a world engaged on the path of secularization. In the fully technologized world in which Dunbar lives, the wheel of fortune is replaced by the ups and downs of public exposure. The notion that humans are mere actors on the stage of life is rendered by St Aubyn in his protagonist's sensation that his demise, orchestrated at a micro-level by his "pelican" daughters, is actually managed skilfully and offhandedly at a macro-level by an invisible demiurge, whose omnipotence can be likened only with that of a media tycoon:

Organisation, disorganization: all these maddening words that treated him as their ventriloquist's dummy, not to mention the images of humanely slaughtered tigers that flickered across the deep grey screen of his television mind, because some bastard, some sadistic sky-god who owned all the channels to all the minds of all living creatures everywhere was playing with the programming and the remote control. (St Aubyn 145-6)

If the world is a stage, a consummate actor must be a welcome addition to the gallery of tragic characters, a living embodiment of the Shakespearean metaphor. Peter, locked up in the same retirement home as Dunbar, suffers from a professional deformation which makes him speak in many voices but which also causes him to fail to regain his own. A Harley Street consultant, Peter offers Dunbar psychological support. In the voice of a bishop, he delivers a sermon. More self-confident than a politician, he addresses an angry mob. But, when asked to be himself, he laments: 
Oh, I haven't got that one down yet, Henry. Give me someone easier to impersonate. How about John Wayne? [...] We're goin' to bust out of this joint, Henry,' he drawled, 'and by sundown tomorrow we'll be walkin' into the Windermere Saloon and ordering a couple of drinks from the bartender, like a couple of real men in charge of our own destinies. (St Aubyn 7)

At the same time, taking the cue from Marjorie Garber's observation that it is mainly due to the modern media that Shakespeare today is a version of the original, we can argue that St Aubyn's transformation of Lear's medieval kingdom into a media empire is yet another mise en abyme of the Bard's assimilation by modern culture. Garber thinks that the Shakespeare cited, worshipped, invoked today is a "Shakespeare," in inverted commas, since what else can be a phrase like "a downfall of Shakespearean proportions," used to characterize a politician's or boxer's career (Garber 17)? In accordance with this parallel, the notion of appropriation used in Shakespeare reception studies should be replaced with other words from the vocabulary of the modern and postmodern media: disseminated, shared, sampled, texted. They are all interactive concepts - as seen above in the presentation of a Shakespeare plot deemed fit for video games-resulting from a "dislocation from context" (Garber 18, italics in the original).

St Aubyn presents here not only power as perverted by the media, but also the simplest of emotions and the most natural of human relations. If, in the original tragedy, Lear is offended by the softness which transformed him into a hysterical woman when crying, Dunbar is irritated by his tears because genuine grief - like genuine love and hate - are the easiest to manipulate and to render hollow through mediatization. Feeling sorry and guilty for Simon, the vicar whose life and career Dunbar's corporation destroyed dispassionately in search of a juicy, money-winning story, the mogul meditates:

He knew how the world worked: the fireman was an arsonist, the assassin came dressed as a physician, the devil was a bishop harvesting souls for his master, teachers entrusted with children filmed them in the shower and posted their naked bodies on the dark net; he had read the stories, he had read them every morning with his breakfast. Like a puppetmaster who pulls the strings but still has to do the voices for his puppets, Dunbar was partially, if superciliously, merged with his ideal reader. (St Aubyn 151)

In King Lear, the patriarchal patterns of the early modern family regulated an ideal of "distance, manipulation, and deference" (Kahn 253), which divided gender roles as they divided labour, advising men never to show powerful emotions other than anger. Conversely, in Dunbar's world, the emotions are no longer regulated by the law of the father, but by the pressures of visibility, publicity, and consumerism. While Lear's tragic story has been narrated in the 
conspicuous "absence" of the mother, Edward St Aubyn rereads it by inserting not one, but three mothers in the narrative. For the early modern play, the fact that the pater familias was the only person of authority, sole progenitor and regulator, and thus, sole beneficiary of filial love and duty, was not exceptional. No queen mediated the familial connections, being supposedly dead or repudiated, as many queens had been indeed, during the Tudors' rule. The irony of this absence, Coppélia Kahn observes, lies in the fact that, eventually, the king seeks for nothing else but the mother, his plan to depend on his daughters, preferably the youngest (gentlest, most affable and most feminine) being, as he announces "I [...] thought to set my rest / On her kind nursery." (1:1:123-4) This paradox becomes a part of Lear's tragic flaw: he dreams to have absolute control while being completely dependent, just as he wants to be treated as a king even after he has given up the crown.

St Aubyn's response comes after a century of psychoanalytical studies and decades of feminist thought, so he anchors the mother figure firmly in the background of the tragedy. First, there is the mother who was deemed absent in King Lear. Wilson remembers a neurotic woman, wearing tacky clothes, already drunk before noon, reluctantly engaging in a game of golf Dunbar wants to play with his entire family. Meghan and Abby, Dunbar's elder daughters, whose cruelty and promiscuousness shocks more than Shakespeare's originals because they are more explicit and detailed, blame their constant dissatisfaction and search for adrenalin on the mother's neglect and alcoholism. Second, there is Henry Dunbar's mother, in whose atmosphere of "punitive rages" (St Aubyn 128) he was forced to grow up, developing a deep sense of resignation, more suited to very old people than to little boys: "the experience [...] belonged to a time when he couldn't imagine it ending" (St Aubyn 128). This continued abuse seems to have determined Dunbar to become obsessed with control and the need to subordinate everyone, from family and employees, to those who became the subject of his news. "Put them on the payroll" is a phrase he repeats endlessly, until it verges on absurdity. Third, there is Florence-Cordelia, an actual mother of two, happily married and leading a healthy, tranquil life on a ranch, after refusing to accept shares in her father's business. Her integrity, high moral standards and devotion to family life determine her to stay away from the power conveyed by media control, a position her sisters embrace because they see the news they sell primarily as "an instrument of revenge" (St Aubyn 87). If Cordelia was, in Kahn's interpretation of King Lear, a symbolic mother to her own father, Florence has the true experience of motherhood, which places her in antithesis with her barren sisters. Her choice to stay away from the media empire is justified by her desire to embrace domesticity and reject public life, while Abby and Meghan's desperate attempt to fully control the same media empire presents their life in the limelight as compensation for the absence of personal fulfilment. 


\section{Conclusion}

The quality of these rewritings is, first and foremost, in my opinion, to be found in its versatility. It is close enough to the early modern playwright's intention to invite contemporaries to meditate on the valences of his stories, beyond the labels that have so frequently been applied to them by criticism. At the same time, it departs from the original plots and meanings enough to present some brilliant novels in their own right, which blend particular elements of AngloAmerican culture with universal and atemporal themes of love and loss, creation and destruction, death and rebirth. Writing Shakespeare-inspired stories, in which modern mediums of communication play an important role, is a successful choice because it capitalizes on the process of validating and legitimizing the four-hundred-year-old plays for the contemporary public. Shakespeare's use in video games, in alternative, unconventional educational environments and in the audio-visual presents three of the most successful ways in which the Elizabethan author has been claimed, keeping the reception process dynamic and the general public alert and sensitive to the myriad of opportunities offered by the original text.

\section{WORKS CITED}

Atwood, Margaret. Hag-Seed. London: Hogarth Shakespeare, 2016.

- Selected Poems 1965-1975. Boston: Houghton Mifflin Company, 2013.

- Surfacing. 1972. New York, London: Anchor Books, Doubleday, 1998.

- Survival: A Thematic Guide to Canadian Literature. 1972. Sydney: ReadHowYouWant, 2013.

Chevalier, Tracy. New Boy. London, New York: Hogarth Shakespeare, 2018.

Desmet, Christy and Robert Sawyer, eds. Shakespeare and Appropriation. New York: Routledge, 1999.

Dollimore, Jonathan and Alan Sinfield, eds. Political Shakespeare. Essays in Cultural Materialism. Manchester: Manchester University Press, 1994.

Garber, Marjorie. Shakespeare and Modern Culture. New York: First Anchor Books, 2009.

Gopnik, Adam. “Why Rewrite Shakespeare?” The New Yorker, 17 October 2016. https:// www.newyorker.com/magazine/2016/10/17/why-rewrite-shakespeare. 1 August 2019.

Groskop, Viv. "Hag-Seed review: Margaret Atwood turns The Tempest into a perfect storm.” The Guardian, 10 October 2016. https://www.theguardian.com/books/ 2016/oct/16/hag-seed-review-margaret-atwood-tempest-hogarth-shakespeare. 1 August 2019. 
Jacobson, Howard. Shylock is My Name. London, New York: Hogarth Shakespeare, 2016.

Kahn, Coppélia. "The Absent Mother in King Lear." The Discourses of Sexual Difference in Early Modern Europe. Ed. Margaret W. Ferguson, Maureen Quilligan, and Nacy J. Vickers. Chicago: University of Chicago Press, 1986. 239-262.

Lamb, Charles and Mary Lamb. Tales from Shakespeare. 1872. London: Penguin Books, 2007.

Nerval, Gérard de. Selected Writings. Trans. Richard Sieburth. London: Penguin Books, 1999.

Nesbø, Jo. Macbeth. London, New York: Hogarth Shakespeare, 2018.

Shakespeare, William. Shakespeare's Romances and Poems. Ed. David Bevington. New York: Longman, 2006.

Shakespeare, William. Shakespeare's Tragedies. Ed. David Bevington. New York: Longman, 2006.

St Aubyn, Edward. Dunbar. London, New York: Hogarth Shakespeare, 2018.

Tyler, Anne. Vinegar Girl. London, New York: Hogarth Shakespeare, 2017.

Winterson, Jeanette. The Gap of Time. London: Vintage, 2015. 